\title{
Constraints That Prevent Tour Firms from Serving Physically Impaired Tourists in Kenya
}

\author{
Kipchirchir Ronoh* Anthony Pepela Samuel Mwakubo \\ School of Business and Economics, Pwani University, Po Box 195-80108, Kilifi, Kenya
}

\begin{abstract}
The number of people living with disabilities is increasing. It is projected that by the end of 2020 , there will be over 1.2 billion people living with disability. Notwithstanding, accessibility provisions of this population remains few. Studies reveal that, many tourism destinations have not adequately provided facilities, information for physically impaired tourists. This study therefore sought to know the constraints that face tour firms from the providing for physically impaired tourist by sampling 104 tour firms and agencies in Kenya. A QUAN-QUAL approach was used to investigate this phenomenon. Data was analyzed using descriptive statistics. Findings of this study reveal that there are a myriad of constraints that tour firms face including the following: The inclusion of dimensions of access, particularly for vision, hearing impairments; Operationalizing information in access, accuracy, detail, format, and presentation dimensions; Inclusion in organizing personalized trips for physically impaired tourists; The inclusion of tourism access information in generic marketing; Destination accessibility; Linkages between transport, the natural and built environments (attractions/parking/activities/ accommodation/services/natural areas e.t.c); Availability and cost of hiring attendants/skilled guides who can handle physically impaired tourists; Costs of adapting transport systems for physically impaired tourists. These findings will facilitate, policy planning, programming and implementation of policies that will see an increased utake of accessible tourism in Kenya.
\end{abstract}

Keywords: Accessible Tourism/Disabled tourism, physically impaired tourists, Impairment, Disability, Universal design

DOI: $10.7176 /$ RHSS/9-18-07

Publication date:September $30^{\text {th }} 2019$

\section{Introduction}

To enhance a positive tourist experience, a basis for tourism business sustainability, the tourism industry must be keen on all the areas that give value to it. Luiza (2010) highlights accessibility as one of the key areas of sustainable tourism. Accessibility is a fundamental facet for responsible and sustainable tourism policy. It is both an incomparable business opportunity and a human rights imperative (Darcy \& Buhalis, 2011). That notwithstanding, it is important to realize that accessible tourism does not benefit the impaired alone, but everyone.

\section{Demand for accessible tourism}

According to WHO (2018), there are over 1 billion disabled people in the world. Together with their families, it is estimated that a third of the world's population is directly or indirectly affected by disability. This population commands over \$1 trillion of disposable income annually. Studies have projected that the number of people living with disabilities will rise because of the ageing population and the increasing number of chronic diseases. While the numbers increase, there is a need to keep an emphasis on providing equitable products, services, and experiences for all. The current emphasis on accessibility and inclusion has brought forth increased exploration to concepts underpinning the emergent disabled tourism segment which consist of; tourists who have wideranging levels of accessibility needs (Miller \& Kirk, 2002). Developing accessible tourism products for the physically impaired tourists' (a niche market) is a milestone in ensuring accessibility for all. Accessible tourism for all does not focus on providing alternative access for impaired tourists, but rather seek to pursue the creation of environments that are universally designed. The concept of accessible tourism is the core of universal design principles. These principles include; equitable use; flexibility in use; simple and intuitive use; perceptible information; tolerance for error; low physical effort; size and space for approach and use. The scope of application of universal design in infrastructure and services makes it a requisite for destinations to give emphasis on tourism information, transportation, architectural environment, tourism activities, accommodation and food service. The design also put staff training as a central element in addressing the needs of physically impaired tourists. The training is vital to reduce accessibility deficiencies by promoting disability awareness, customer service and care to minimize barriers. Well trained staffs are able to; perceive and address physically impaired tourists needs; provide better assistance; better communication; good customer care; and to provide complete information (Norain, Siti, Taha, \& Maslina, 2008). Even with this understanding, studies indicate that the accessible tourism market has been discriminated by the travel and tourism industry. Studies have found out that over 500 million people living with disabilities do not take holidays because many of the available tourism 
offers are not accessible. This study sought to establish the constraints that prevent tour firms from serving physically impaired tourists in Kenya.

\section{Methodology}

The study adopted a QUANTI-QUAL research design. The study's research instruments included an observation checklist and a self-administered questionnaire. The study's was done in Nairobi and Mombasa. The study targeted Tour firms since they play a critical role in the hospitality and tourism service chain. From a population of 307 tour firms pulled from Kenya Association of Tour Operators, a sample of 104 tour firms was proportionately selected. The study used purposive sampling technique to target one management employee from each of the sampled tour firms. Data was analyzed using descriptive statistics.

\section{Findings}

To determine the constraints that prevent tour firms from serving physically impaired tourists, a descriptive statistic was run (see table below). The study investigated 8 factors under the constraint variable. These factors included: (i) Inclusion in organizing personalized trips for physically impaired tourists- var1; (2) Availability and cost of hiring attendants/skilled guides who can handle physically impaired tourists- var2; (3) Inclusion of dimensions of access, particularly for vision, hearing impairments- var3; (4) Provision of alternative communication technology/assistive devices- var4; (5) Costs of adapting transport systems for physically impaired tourists- var5;(6)Operationalizing information in access, accuracy, detail, format, and presentation dimensions- var6; (7) Inclusion of tourism access information in generic marketing- var7; (8)Destination accessibility; Linkages between transport, the natural and built environments (attractions/parking/activities/ accommodation/services/natural areas- var8.

Descriptive statistics for constraints that prevent tour firms' from serving physically impaired tourists

\begin{tabular}{|c|c|c|c|c|c|c|c|c|c|}
\hline & & $\bar{\Xi}$ & $\stackrel{\overparen{E}}{>}$ & 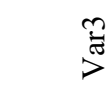 & 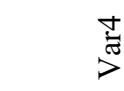 & $\stackrel{\Xi}{>}$ & 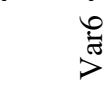 & $\widehat{\bar{z}}$ & $\stackrel{\infty}{\stackrel{\infty}{\Xi}}$ \\
\hline \multirow[t]{2}{*}{$\mathrm{N}$} & Valid & 94 & 94 & 94 & 94 & 94 & 94 & 94 & 94 \\
\hline & Missing & 0 & 0 & 0 & 0 & 0 & 0 & 0 & 0 \\
\hline \multicolumn{2}{|c|}{ Mean } & 3.5213 & 3.2979 & 3.6064 & 2.8830 & 3.0213 & 3.5319 & 3.4681 & 3.3511 \\
\hline \multicolumn{2}{|c|}{ Std. Deviation } & .88874 & .94845 & .81936 & 1.02502 & 1.02631 & .85134 & .90044 & .95835 \\
\hline \multicolumn{2}{|c|}{ Skewness } & -1.052 & -.711 & -1.189 & .362 & .201 & -1.063 & -1.167 & -.687 \\
\hline \multicolumn{2}{|c|}{$\begin{array}{l}\text { Std. Error of } \\
\text { Skewness }\end{array}$} & .249 & .249 & .249 & .249 & .249 & .249 & .249 & .249 \\
\hline
\end{tabular}

Factor mean score close to 1 represents a low mean in a 5 point likert scale (where $1=$ Strongly disagree, $2=$ disagree, $3=$ neither, $4=$ agree $5=$ strongly agree)

The investigated factors expect factor 4 scored high means $(\bar{x}=$ (var1)3.52513; (var2) 3.2979; (var3)3.6064; (var4) 2.8830; (var5) 3.0213; (var6) 3.5319; (var7) 3.4681; (var8) 3.3511) respectively. This implies that there were a number of constraints that prevented most of the tour firms from serving physically impaired tourists. This implication is cannot conclusively explain the moderate mean for provision of alternative communication technology/assistive devices. It was therefore imperative to further investigate the factors and to establish the distribution of the data points. This would help to accurately explain the implications of the variables. To this end descriptive statistics (percentages and frequencies) were run. 


\begin{tabular}{|c|c|c|c|c|c|c|c|}
\hline & & 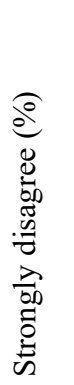 & 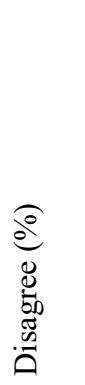 & 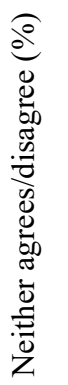 & 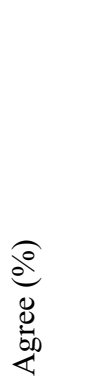 & 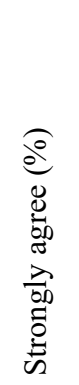 & 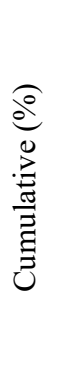 \\
\hline i) & $\begin{array}{l}\text { Inclusion in organizing personalized trips for } \\
\text { physically impaired tourists }\end{array}$ & 1.1 & 20.2 & 7.4 & 68.1 & 3.2 & 100 \\
\hline ii) & $\begin{array}{l}\text { Availability and cost of hiring attendants/skilled } \\
\text { guides who can handle physically impaired tourists }\end{array}$ & 1.1 & 30.9 & 5.3 & 62.8 & & 100 \\
\hline iii & $\begin{array}{l}\text { The inclusion of dimensions of access, particularly } \\
\text { for vision, hearing impairments }\end{array}$ & & 18.1 & 6.4 & 72.3 & 3.2 & 100 \\
\hline$i v$ & $\begin{array}{l}\text { Provision of alternative communication } \\
\text { technology/assistive devices }\end{array}$ & 1.1 & 52.1 & 7.4 & 36.2 & 3.2 & 100 \\
\hline v) & $\begin{array}{l}\text { Costs of adapting transport systems for physically } \\
\text { impaired tourists }\end{array}$ & & 46.8 & 8.5 & 40.4 & 4.3 & 100 \\
\hline$v i$ & $\begin{array}{l}\text { Operationalizing information in access, accuracy, } \\
\text { detail, format, and presentation dimensions }\end{array}$ & & 21.3 & 6.4 & 70.2 & 2.1 & 100 \\
\hline$v i$ & $\begin{array}{l}\text { The inclusion of tourism access information in } \\
\text { generic marketing }\end{array}$ & 2.1 & 20.2 & 7.4 & 69.1 & 1.1 & 100 \\
\hline$v i$ & $\begin{array}{l}\text { Destination accessibility; Linkages between } \\
\text { transport, the natural and built environments } \\
\text { (attractions/parking/activities/ } \\
\text { accommodation/services/natural areas e.t.c) }\end{array}$ & 1.1 & 28.7 & 6.4 & 61.7 & 2.1 & 100 \\
\hline & Valid N (listwise) 94 & & & & & & \\
\hline
\end{tabular}

\subsection{Inclusion in organizing personalized trips for physically impaired tourists}

In trying to establish the constraints (if any) that tour firms face in inclusion in personalizing trips for physically impaired tourists, the study recorded a mean of $\overline{\mathrm{x}}=3.52$ and a standard deviation of $\mathrm{SD}=0.88874$. From the frequency table above, $71.3 \%(68.1 \%+3.2 \%)$ of the respondents found it challenging to organize personalized trips for physically impaired tourist. $21.3 \%(1.1 \%+20.2 \%)$ of the respondents never saw inclusion in organizing personalized trips for physically impaired tourists a major constraint to accessible tourism. Still, $7.4 \%$ of the respondents were not decided on the factor. It is evident from the distribution of these percentages that a majority of tour firms agreed to be facing constraints relating to inclusion in organizing personalized trips for physically impaired tourists.

4.2 Availability and cost of hiring attendants/skilled guides who can handle physically impaired tourists As to whether the availability and cost of hiring attendants/skilled guides who can handle physically impaired tourists was a challenge, the study recorded a mean of $\bar{x}=3.2979$ and a standard deviation of $\mathrm{SD}=0.94845$. This mean was moderately high. From the percentages in table above $62.8 \%$ (slightly above average) of the respondents agreed that availability and cost of hiring attendants/skilled guides who can handle physically impaired tourists was a constraint they faced. $32 \%$ of the respondents never saw it as a challenge to find and hire skilled guides to handle physically impaired tourists. A few (5.3\%) of their tour firms were undecided on whether/not the factor under study was a constraint to accessible tourism. These findings imply that many tour firms faced challenges in relation to finding and hiring skilled attendants. This score could either mean that skilled attendants were scarce or hiring one could mean extra overhead costs.

\subsection{The inclusion of dimensions of access, particularly for vision, communication impairments}

The factor of inclusion of dimensions of access for vision and communication impairments scored a high mean of $\bar{x}=3.6$ and a standard deviation of $\mathrm{SD}=0.81936$. The percentages of respondents who agreed; those who disagreed; and those who were undecided that Inclusion of dimensions of access, particularly for vision, 
communication impairments was a constraint they faced in accessible tourism were; $75.3 \%(72.3 \%+3.2 \%)$, $18.1 \%$, and $6.4 \%$ respectively. From these findings, it can be implied that a majority of tour firms saw it a challenge to integrate dimensions of access, particularly for vision, communication impairments.

\subsection{Provision of alternative communication technology/assistive devices}

This factor recorded a moderately low mean $(\overline{\mathrm{x}}=2.8330)$ and a standard deviation of $\mathrm{SD}=1.02502$. From the findings, it is evident that a moderate percentage $(53.2 \%)$ of tour firms did not find it a challenge to provide alternative communication technology/assistive devices. It also evident that some tour firms (39.4\%) found it challenging to provide alternative communication technology/assistive devices for physically impaired tourists. A few respondents could neither agree/disagree that the aforementioned factor was a constraint to accessible tourism. These findings imply that the number of tour firms who did not find this factor a constraint is as significant to those who found it a constraint. There is also a possibility that some tour firms were not aware of the aforesaid technologies and therefore never considered it a challenge.

\subsection{Costs of adapting transport systems for physically impaired tourists}

The costs of adapting transport systems for physically impaired tourists variable had a moderately high mean of $\overline{\mathrm{X}}=3$ and a standard deviation of $\mathrm{SD}=1.02631$. The corresponding percentages for those who considered and those who did not consider costs of adapting transport systems for physically impaired tourists a constraint were $72.3 \%(70.2 \%+2.1 \%)$ and $21.3 \%$ respectively. From the findings, it can be said that, to many of the tour firms, the costs of adapting transport systems for physically impaired tourists was a constraint.

\subsection{Operationalizing information access, accuracy, detail, format, and presentation dimensions}

The constraint factor of operationalizing information access, accuracy, detail, format, and presentation dimensions recorded a high mean of $\overline{\mathrm{x}}=3.5$ and a standard deviation of $\mathrm{SD}=0.85134$. This mean represented $46.8 \%$ of those who disagreed; $44.7 \%(4.04 \%+4.3 \%)$ of those who agreed; and $8.5 \%$ of those who were undecided that operationalizing information access, accuracy, detail, format, and presentation dimensions was a constraint. This implies that there were an almost equal number of tour firms who agreed to those who disagreed that this factor was a constraint.

\subsection{The inclusion of tourism access information in generic marketing}

As per the recorded high mean score of $\bar{x}=3.5$ and standard deviation of $\mathrm{SD}=0.90044$, it is evident that tour firms found challenges in the inclusion of tourism access information in their generic marketing endeavors. This is evident from comparative percentages for those respondents who agree to those who disagreed to be facing constraints relating to the Inclusion of tourism access information in generic marketing. The number of respondents who agreed that the aforementioned factor was a constraint was high at $70.2 \%(69.1 \%+1.1 \%)$ compared to $20.2 \%$ (those who disagreed). It can, therefore, be implied that a majority of tour firms find it challenging to integrate tourism access information in generic marketing. This further implies that tour firms had scantily integrated access information for physically impaired tourists to their generic marketing mediums.

\subsection{Destination accessibility; Linkages between transport, the natural and built environments (attractions/parking/activities/ accommodation/services/natural areas)}

This dimension scored a mean of $\bar{x}=3.35$ and a standard deviation of $\mathrm{SD}=0.95835$. The corresponding percentages for those who disagreed to those who agreed that this factor was a constraint to accessible tourism were $29.8 \%(1.1 \%+28.7 \%)$ and $63.8 \%(61.7 \%+2.1 \%)$ respectively. This implies that a majority of tour firms saw it a challenge to find accessible destinations, attractions, accommodation services, and natural areas for their physically impaired tourists. This factor is more of an extrinsic challenge to what tour firms have done to make their facilities (tour vans/buses) accessible. There is a possibility that some tour firms were accessible (adapted facilities-tour vehicles, accessible info, skilled employees). However, there was a disconnect between them and the destinations (inaccessible attractions/parking/activities/accommodation/services/natural areas).

\section{Discussion}

A possible explanation to the constraint in destination accessibility (var8), inclusion in personalizing trips for physically impaired tourists (var1), and Operationalizing information in access, accuracy, detail, format, and presentation dimensions (var6), is the fragmented nature of tourism elements in the service chain. Accessible tourism experience for physically impaired tourists is enhanced if the complete service chain is included. Isolated offers of individual players in the service chain fail when other providers in the customer path are not integrated when preparing for physically impaired tourists. Coordination and harmonization of individual tourism elements in the customer service chain is very important (ADAC, 2003). This is the reason why physically impaired tourists need to make a significantly greater amount of pre-planning to take on travel than 
the non-impaired. If further explains the reason why destination management organizations including tour firms are challenged when all-inclusive tour packages are to be designed. Also, it is solely hard for tour firms to create a comprehensive accessible tourism product alone. Future studies should, therefore, consider investigating constraints in the entire service chain rather than isolating one service provider in the chain (tour firms) to be representative. A possible explanation to the high mean for the constraint of obtaining skilled attendants (var2) is that tourism industry as a whole has not seen the significance of accessible tourism, and thereby failing to equip their staff with requisite skills. It is evident in other scholarly works that the level of understanding and qualifications of tourism service providers is lacking to address the needs of physically impaired tourists. There is an insistent need to put emphasis on instilling tourism service providers with knowledge on accessibility through training. A possible explanation for the constraints related to information access (var3 and var7), particularly for vision, hearing impairments is that; tour firms are not aware of the different dimensions of access. This could be as a result of lack of a shared understanding of what represents access and disability by tour firms. It is also possible to explain this scenario to lack of knowledge about accessible tourism and thereof inadequate skills to integrate dimensions of access to mainstream tourism.

\section{Conclusion and Recommendations}

Findings of this study reveal that that there were many constraints that prevented tour firms from serving physically impaired tourists. These constraints include:

- The inclusion of dimensions of access, particularly for vision, hearing impairments.

- Operationalizing information in access, accuracy, detail, format, and presentation dimensions.

- Inclusion in organizing personalized trips for physically impaired tourists.

- The inclusion of tourism access information in generic marketing.

- Destination accessibility; Linkages between transport, the natural and built environments (attractions/parking/activities/ accommodation/services/natural areas e.t.c).

- Availability and cost of hiring attendants/skilled guides who can handle physically impaired tourists.

- Costs of adapting transport systems for physically impaired tourists.

This finding can be useful to tour firms in designing accessible packages for physically impaired tourists. This finding is equally important for tour firms to help them explore the means of packaging and availing marketing information that is accessible to all. Nevertheless, this finding will help policymakers in crafting policies and legislation that will create accessible destinations and encourage the uptake of accessible tourism in a sustainable manner. Further, understanding the information needs of physically impaired tourists will enable destination marketers to come up with marketing initiatives that will facilitate the uptake of accessible tourism. Destination marketers such as KTB should work together with tour operators to identify attributes which influence physically impaired tourists' choice of accessible destinations. This will enable them to craft effective targeting and positioning strategies for accessible offers in the tourism industry/destinations.

\section{References}

Aitchison, C. (2003). "From leisure and disability to disability leisure: developing data, definitions and discourses", Disability and Society, Vol. 18 No. 7, pp. 955-69.

A.F.U.B. (2007). State of Disabled Peoples' Rights in Kenya (2007) Report. Nairobi, Kenya: African Union of the Blind.

Badaruddin, M., Azizi, B., \& Shida, I. (2008). The Evolution of Domestic Tourism in Malaysia.

Buhalis, D., Eichhorn, V., Michopoulou, E., \& Miller, G. (2005). Accessibility market and stakeholder analysis. University of Surrey y One Stop Shop for Accessible Tourism in Europe (OSSATE).

Buj, C. (2010). Paving the Way to Accessible Tourism. International Centre for Responsible Tourism; Leeds Metropolitan University.

Breedt, T. (2007). The need for disabled friendly accommodation in south africa

BMWA - Bundes ministerium für Wirtschaft und Arbeit (2004). Economic Impulses of Accessible Tourism for All Report. Berlin. Federal Ministry of Economic and Labour.

Burnett, J.J. and Bender Baker, H. (2001), "Assessing the travel-related behaviors of the mobility-disabled consumer", Journal of Travel Research, Vol. 40 No. 1, p. 411.

Chen, S. C., \& Shoemaker, S. (2014). Age and cohort effects: The American senior tourism market. Annals of Tourism Research, 48, 58-75.

Çağıl, H., \& Nazmi, K. (2008). Measuring Destination Competitiveness. An Application of Travel and Tourism Competitiveness Index.

Darcy, S. (1998), "People with a disability and tourism bibliography", Bibliography No.7, available at: www. business.uts.edu.au/lst/downloads.07_Disabiliy_Tourism.pdf

Darcy, S. (2006). Setting a Research Agenda for Tourism. Sustainable Tourism Cooperative Research Centre 
(STCRC). Australia: CRC for Sustainable Tourism Pty Ltd.

Darcy, S., \& Dickson. (2009). A Whole-of-Life Approach to Tourism: The Case for Accessible Tourism Experiences. Journal of Hospitality and Tourism Management, 16(1), 32-44.

Darcy, S. (2010). Inherent complexity- Disability, accessible tourism and accommodation information preferences. Tourism Management, 31(6), 816-826.

Darcy, S. and Pegg, S. (2011), "Towards strategic intent: perceptions of disability service provision amongst hotel accommodation managers", International Journal of Hospitality Management, Vol. 30 No. 2, pp. 46876.

Department for Culture Media and Sport (2010), Accessible tourism: Making it work for your business.

Desmond O. BROWN . (2008). Using Participatory Rural Appraisal Approach to Conduct Tourism Skills Development Training among Women in Africa .

Dimitrios Buhalis, Simon Darcy. (2011). Accessible Tourims: Concepts and Issues. Channel View Publications.

Dickson, T. J., Darcy, S., Johns, R.,\& Pentifallo, C. (2016). Inclusive by design: transformative services and sport-event accessibility. The Service Industries Journal, 36(11-12), 532- 555.

Dwyer, L. and Darcy, S. (2008), "Chapter 4-economic contribution of disability to tourism in Australia", Technical Report, 90040, pp. 15-21.

disabled-world.com. (2016, 08 9). UN Says Accessible Tourism Benefits Everyone. Retrieved 05 10, 2017, from disabled-world: https://www.disabled-world.com/travel/everyone.php

Dwyer, L., Forsyth, P., \& Prasada Rao. (2000). The price competitiveness of travel and tourism: a comparison of 19 destinations. Tourism Management, 9-22.

Eichhorn, V., Miller, G., Michopoulou, E., \& Buhalis, K. D. (2008). Enabling Access to Tourism through Information Schemes. Annals of Tourism Research, 35(1), 189-210. doi:10.1016/j.annals.2007.07.

Ells, C. (2001), "Lessons about autonomy from the experience of disability", Social Theory and Practice, Vol. 27 No. 4, pp. 599-615.

Eurobarometer (2001), "Attitudes of Europeans to disability", European Commission, Brussels, available at: http://europa.eu.int/comm/public_opinion/archives/eb/ebs_149_en.pdf

European Network for Accessible Tourism (2007), Rights of Tourist with Disabilities in the European Union Framework, Fundacion ONCE, Athens.

Federal Ministry of Economics and Technology. (March 2004). Economic Impulses of Accessible Tourism for All, Summary of results. Berlin: Federal Ministry of Economics and Technology.

Fink, A. (2003). How to Design Survey Studies. London: SAGE Publications Incorporated.

European Comission. (n.d.). Mapping and Performance Check of the Supply of Accessible Tourism ServicesCase Study 9 Moravian-Silesian Region, Czeck Republic .

European Commission Directorate. (n.d.). General Enterprise And Industry Directorate- General Justice. Accessible Tourism In Europe .

HorganJones, M.andRingaert, L. (2004), "Accessible tourism in Manitoba”, available at: www.ttra.com /pub/ uploads/AccessibleTourismInManitoba.htm (accessed 30 November 2014).

Hsu, C. and Powers, T. (2002), Marketing Hospitality, John Wiley and Sons, New York, NY.

Gaunette SINCLAIR - MARAGH. (2008). An Assessment of the Positioning of Jamaica's Tourism Product in this Dynamic Global Environment.

Gale, C. R., Cooper, C., \& Sayer, A. A. (2015). Prevalence of frailty and disability: findings from the English Longitudinal Study of Ageing. Age and ageing, 44(1), 162-165.

hotels.com. (2017). hotels.com. Retrieved 09 28, 2017, from hotels.com: hotels.com

Ivanov, S. H., \& Webster, C. (2017). Tourism's contribution to economic growth. A global analysis for the first decade of the millenium

Johnson, K. (2007). Pre-test Preparation for Survey Research. PA: Survey Research Centre Penn State University.

Kenya Tourism Board. (2016). Sustainable Tourism Report. Nairobi: Kenya Tourism Board.

Kumar, K., Rajkumar, S., \& Ujjwal, M. (2012). A Study of Accessibility in Hotel Chains, Public Transportation and Ferry Companies in Helsinki. AccessibleTourism,.

Luiza, S. M. (2010). Accessible Tourism-The Ignored Opportunity. The Journal of the Faculty of EconomicsEconomic, 1(2), 1154-1157

Martin, L. G., \&Schoeni, R. F. (2014). Trends in disability and related chronic conditions among the forty-andover population: 1997-2010. Disability and health journal, 7(1), 0 S4-S14.

Murungi, c. M. (2010). Choice of hotel facilities by guests with physical disabilities in nairobi, Kenya. Choice of hotel facilities by guests with physical disabilities in nairobi, Kenya.

McKercher, B., Packer, T., Yau, M.K. and Lam, P. (2003), "Travel agents as facilitators or inhibitors of travel: perceptions of people with disabilities", Tourism Management, Vol. 24 No. 4, pp. 465-74.

Miller, G. and Kirk, E. (2002), “The Disability Discrimination Act: time for a stick?” Journal of Sustainable 
Tourism, Vol. 10 No. 1, pp. 82-8.

Mute, L. (2017). Accessibility as a right:Thoughts on priorities for persons with disabilities in Kenya. Retrieved 09 28, 2017, from knhcr: knhcr.org

Nishimura, S., King, B., \& Waryszak, R. (2007). The Use of Travel Guidebooks By Packaged And NonPackaged Japanese Traveller: A Comparative Study. Journal of Vacation Marketing pp. 291-310. .

Nitchakarn, N.-u., \& Kaedsiri, J. (2017). The Sustainability Marketing Mix for Thai Senior Tourism. International journal of social sciences, 4(2), 80-89. doi:10.3126/ijssm.v4i2.17157

OSSATE. (2005). One-Stop-Shop for Accessible Tourism Annual Report. Retrieved June 2009, from One-StopShop for Accessible Tourism Website: http://www.ossate.org/docs/OSSATE_D1.3_Annual_Public_Report_2005_public.pdf.

Pitipong, Y., Korawan, S., \& Napaporn, R. (2015). Knowledge Audit for Senior Tourism Standards in Northern Thailand. doi:doi:10.5539/ass.v11n28p248

Rosenberg, D., Bombardier, C., Hoffman, J. and Belza, B. (2011), "Physical activity among persons ageing with mobility disabilities: shaping a research agenda", Journal of Ageing Research, Vol. 2011, pp. 1-16, Article ID 708510.

Simion, D., \& Shane, P. (2011). Towards strategic intent: perceptions of disability service provision amongst hotel accommodation sector managers

Simon, D., Bruce, C., \& Shane, P. (2010). Accessible tourism and sustainability: a discussion and case study. , 18(4), 515 - 537. Journal of Sustainable Tourism, 18(4), 515-537.

Smith, J. (2013, 09 17). Will Accesible Tourism soon be the largest travel market? Retrieved 05 10, 2017, from wtm Responsible Tourism: http://blog.wtmresponsibletourism.com/2013/09/17/accessible-tourism-largesttravel-market/

Shaw, G. and Coles, T. (2004), "Disability, holiday making and the tourism industry in the UK: a preliminary survey", Tourism Management, Vol. 25 No. 3, pp. 397-403.

Shaw, G., Veitch, C. and Coles, T.I.M. (2005), "Access, disability, and tourism: changing responses in the United Kingdom”, Tourism Review International, Vol. 8 No. 3, pp. 167-76.

STRC. (2008). Accessible Tourism: Challenges and Opportunities. Accessible Tourism: Understanding an Evolving Aspect of Australian Tourism. Australia: Sustainable Tourism Cooperative Research Centre (STRC).

Stumbo, N. J., \&Pegg, S. (2005). Travelers and Tourists with Disabilities: A matter of Priorities and Loyalties. Tourism Review International, 8 (3), 195-209

Tinker, A. (2002), "The social implications of an ageing population", Mechanisms of Ageing and Development, Vol. 123 No. 7, pp. 729-35.

United Nations (1990), Disability Statistics Compendium, United Nations, New York, NY.

Van Horn, L. (2002), "Travelers with disabilities: market size and trends", available at: http://ncpedp.org/ access/isu-travel.htm

Vash, C.L. (2001), "Disability attitudes for all latitudes", Journal of Rehabilitation, Vol. 67 No. 1, pp. 38-42.

Vila, T. D., Darcy, S., \& González, E. A. (2015). Competing for the disability tourism market-a comparative exploration of the factors of accessible tourism competitiveness in Spain and Australia. Tourism Management, 47, 261-272.

VictoriaSafaris. (n.d.). Disability travel in africa. Retrieved 05 10, 2017, from Victoria Safaris: http://www.victoriasafaris.com/africa/disabilitytours.htm $\$

Wardlow's, D. M. (2017, 05 09). every customer counts. Retrieved 05 12, 2017, from Equality Commission for Northen Ireland: http://www.equalityni.org/Footer-Links/News/Employers-Service-Providers/Anticipatingthe-needs-of-disabled-customers

Why Accessibility Is Good For Your Business. (2017). Retrieved 05 12, 2017, from accessibility news: http://www.accessibilitynews.ca/cwdo/resources/resources.php?resources $=78$

WHO. (2011). World Report on Disability.

World Health Organization (WHO) (2012), "Disabilities", available at: www.who.int/topics/disabilities/en/

World Tourism Organization. (2016). UNWTO Tourism Highlights. UNWTO Elibrary. Retrieved 9 2017, from http:/www.e-unwto.org/

Yau, M.K.S., McKercher, B. and Packer, T.L. (2004), "Traveling with a disability: more than an access issue", Annals of Tourism Research, Vol. 31 No. 4, pp. 946-60. 